Journal

of Geography

Politics and Society

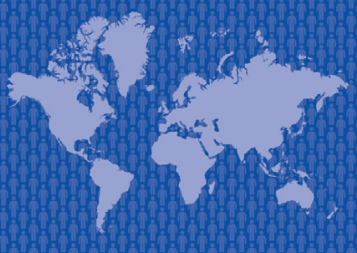

$7(2) / 2017$

\section{Journal of Geography, Politics and Society}

$2017,7(2), 64-72$

DOI 10.4467/24512249JG.17.016.6632

\title{
GEO-CULTURAL RESEARCH OF RELIGIOUS EDUCATION IN WESTERN UKRAINIAN BORDERLAND
}

\author{
Ivan Rovenchak (1), Vasyl Stetskyi (2), Oryslava Tymchuk (3) \\ (1) Chair of Economic and Social Geography, Faculty of Geography, Ivan Franko National University of Lviv, Doroshenka 41, 79000 Lviv, Ukraine, \\ e-mail: ir_pavuk@ukr.net (corresponding author) \\ (2) Chair of Economic and Social Geography, Faculty of Geography, Ivan Franko National University of Lviv, Doroshenka 41, 79000 Lviv, Ukraine, \\ e-mail: stetskyigeo@gmail.com \\ (3) Chair of Economic and Social Geography, Faculty of Geography, Ivan Franko National University of Lviv, Doroshenka 41, 79000 Lviv, Ukraine, \\ e-mail: oryslava.tymchuk@gmail.com
}

\section{Citation}

Rovenchak I., Stetskyi V., Tymchuk O., 2017, Geo-cultural research of religious education in western Ukrainian borderland, Journal of Geography, Politics and Society, 7(2) 64-72.

\begin{abstract}
It has become apparent that there's a need to conduct a study on religious education. I've conducted just such a study of the historical aspects of religious education of the Western region of Ukraine. As a result l've done an analysis of the spatial distribution of religious educational institutions in the western Ukrainian borderland. I've investigated the locations of higher religious educational institutions and various denominations and movements in the region. After much considerations, facts were made available regarding the distribution of religious schools in the Western region, in terms of denominations within their areas.
\end{abstract}

\section{Key words}

western Ukrainian borderland, religious organization, religious community, church, confession, movement, religious educational institutions, religious education, religious school, Sunday school, secondary school.

\section{Introduction}

The research shows that the human and geographical system of the western Ukrainian borderland is the organizational product of modern religious life. In particular, the study of spatial aspects and distribution of major religions, faiths, denominations and religious organizations as well as the functions of higher and secondary religious educational institutions including Sunday schools (sеe Стецький, 2015).
The western Ukrainian borderland includes the following six administrative oblasts: Rivne, Volyn, Lviv, Transcarpathian, Ivano-Frankivsk and Chernivtsi. Their share is $18.4 \%$ of the territory and $16.0 \%$ of the population.

The national education system of Ukraine is organized into three levels, each of them performs its inherent educational objectives. The first level is comprehensive. It comprises children of 1-17 years old who attend pre-school, regular schooling and after-school education. They get a basic understanding of key subjects, physical education and aesthetic 
development. The second level involves training. It comprises young people from 17 to $25-28$ years old. This is made up of three groups of institutions: a) vocational schools that train professionals; b) universities of the I-II level of accreditation (technical schools, colleges) that train specialists in general and special education; c) higher educational institutions, the III-IV level of accreditation (universities, institutes, academies) where students carry a full course of education and receive a bachelor's degrees (basic higher education) and masters (complete higher education). The third level is a post-graduate education and it depends on the requirements of professional training and retraining as labor conditions require, which in turn provides further training for the need of the community as the labor markets require in whatever particular sectors of economic activity.

In 2015/2016 academic year, Ukraine had 659 higher education institutions, including 371 institutions of I-II level of accreditation, 288 institutions of III-IV level of accreditation and 16900 secondary schools. In the western Ukrainian borderland, the situation is as follows: 118 higher education institutions $(17.9 \%$ of the Nationwide Index, $\mathrm{NI}$ ), these include 74 institutions of I-II level of accreditation (19.9\% NI), 44 institutions of III-IV level of accreditation $(15.3 \% \mathrm{NI})$ and 16900 secondary schools $(27.6 \%$ NI) (Державна служба...).

Religious education in the western Ukrainian borderland is a subsystem of religious infrastructure that includes 84 missions, 59 academic institutions and seminaries ( 33 high and 26 medium) and 5601 religious schools (four secondary and 5597 Sunday schools). Religious organizations produce 133 periodicals, including 76 articles, 21 audio-visual (radio and television) and 37 various electronic methods
(Звіт про мережу церков..., 2016). There are also other religious publishing houses as well as various church enterprises.

The subject of our geo-cultural analysis is the religious education of the western Ukrainian borderland. Religious organizations in this region, remains the goal of higher and secondary religious educational institutions including Sunday school.

Human-geographic research of religion, particularly religious education in Ukraine was conducted by such scientists as I.I. Rovenchak, (Ровенчак, 2008), J. Sutton (1994), O.I. Shabliy (Шаблій, 2000), L.T. Shevchuk (Шевчук, 1999) and others. They established the basic foundational principles of spreading religious beliefs and establishing their respective institutions; they also identified geospatial-core centers of religious life, reasonable flows of pilgrims and tourists; identified the territorial aspects of sacred infrastructure; expressed the territorial differentiation of religious life within their historical and geographical backgrounds.

Such scholar as O.G. Kuchabskiy (Кучабський, 2000), V.O. Patiychuk (Патійчук, 1998) and others, addressed the organization and functioning of religious education in Ukraine's various regions. The results of their study confirms the differences within regional education and functional levels of religious schools, seminaries, academies, as well as their territorial location according to the distribution of various denominations.

In 2016, the total number of religious organizations within the religious network of the western Ukrainian borderland are $30.7 \%$ of the National Figure, NF; $23.4 \%$ are missions (NF); $43.4 \%$ are monasteries (NF); $29.8 \%$ are religious educational institutions (NF), $25.6 \%$ of which are higher (NF) and $37.7 \%$

Tab. 1. Religious organizations and their species, number, 2016

\begin{tabular}{|l|l|r|r|}
\hline № & Species of religious organizations & Ukraine & Western Ukrainian borderland \\
\hline 1 & Religious organizations & 35709 & 10977 \\
\hline 2 & Missions & 359 & 84 \\
\hline 3 & Monasteries & 516 & 224 \\
\hline 4 & Religious educational institutions & 198 & 59 \\
\cline { 2 - 4 } & higher & 129 & 33 \\
\cline { 2 - 4 } & secondary & 69 & 26 \\
\hline \multirow{3}{*}{5} & Religious schools & 12179 & 5601 \\
\cline { 2 - 4 } & general & 8 & 4 \\
\cline { 2 - 4 } & Sunday & 12171 & 5597 \\
\hline \multirow{3}{*}{6} & Periodical & 484 & 133 \\
\cline { 2 - 4 } & printed & 329 & 76 \\
\cline { 2 - 4 } & audio-visual & 29 & 21 \\
\cline { 2 - 4 } & electronic & 133 & 37 \\
\hline
\end{tabular}

Source: calculated by the authors. 
are secondary (NF); $46.0 \%$ are religious schools (NF), $50.0 \%$ of which are general (NF) and $46.0 \%$ are Sunday schools (NF). Religious organizations issued periodicals $27.5 \%$ of the (NF), $23.1 \%$ of which were printed (NF), $72.4 \%$ are audio-visual (NF) and $27.8 \%$ are electronic (NF) (Tab. 1.) (Звіт про мережу церков..., 2016).

The first public schools which exist in Ukraine now, were in the care of the church and priests being the teachers. In the second half of the ninth century, almost every cathedral had a school that produced new educators for the government. When the sixteenth century began, church 'brethren' began to create communal schools and 'fraternal' organizations. In 1592, Lviv Dormition Brotherhood, which is also called Stavropigiyska was established. Similarly other 'fraternal' organizations began to emerge throughout the western Ukrainian borderland, in Rohatyn, Tysmenytsi, Lutsk, Volodymyr-Grand, Komarno, Galicia, Stryi, Nikolaev, Dubna and elsewhere. In 1580 Ostroh Academy was founded in the Rivne oblast.

In 1783 the Lviv Theological Seminary was founded and in 1804-1918 Studiyum Ruthenium were established. At Lviv University Theological faculty existed, for both denominations Greek Catholic and Latin. Also, Seminaries began to develop in Przemyśl in modern Poland (1912), Stanisław in Ivano-Frankivsk (1907) and Prešov, in modern Slovakia (Федорів, 2007).

In 1928-1929, Metropolitan Sheptytsky founded the Lviv Greek Catholic Theological Academy, which consisted of two faculties, Philosophy and Theology, and Yosyp Slipyy became rector. After the closure of the Academy in 1944 its mission and functions were taken over by the Ukrainian Catholic University, Pope Clement of Rome, and was reorganized and headed in 1963 by Metropolitan Yosyp Slipyy. In 1994 activity of the Academy was resumed under the name "Lviv Theological Academy", and in 1998 received international accreditation. In 2002 it became the Ukrainian Catholic University.

In Lviv, Seminary of the Holy Spirit, which is the successor to General Seminary, was founded by Austrian Emperor Joseph II in 1783. At that time it was the only seminary of the Catholic Church, which provided theological education and spiritual education to young people from Galicia, Transcarpathia, Presov Region, Kryzhevskiy diocese, Transylvania and Croatia. After the arrival of the Bolsheviks it was closed. But the seminary was restored in 1990 and construction of the new Seminary of the Holy Spirit began in March 2002. It was completed in August of 2005.

Yuriy Fedkovych Chernivtsi National University, established a Theological department in studies of
Philosophy and Theology, which is the historical successor of the Greek Orthodox Theological Faculty. It was the basis for the founding of the University of Chernovtsy in 1875.

For the faithful of the Roman Catholic Church in Bryukhovychi, Lviv Oboist, there exists the Higher Seminary of the Lviv Archdiocese. It was originally founded in 1703, when the Cathedral Seminary was created. In 1783 an Austrian Order in Lviv created the so-called General Seminary for all Galician dioceses, and in 1814 Lviv, the seminary separated from the General Seminary. In 1945 the Lviv Seminary was moved to Kalwaria Zebrzydowska, Poland, and in 1950 the seminary was eliminated. Seminary resumed its operations December 12, 1996.

\section{The description of religious educational sphere in the western Ukrainian borderland}

Geospatial analysis of the western Ukrainian borderland, will be conducted by such indicators as high and medium religious schools, the number of attendees daily and forms of publications; religious schools, which include Sunday schools. Also taken into account performance of religious schools, missions, monasteries and clergy periodicals.

The territorial distribution of religious educational institutions were primarily associated with the historical context of religion in Ukraine and particularly in the western Ukrainian borderland, and the necessity to meet the needs of the faithful. In total there are 58 religious educational institutions of which 33 senior and 25 middle). Most of them in Lviv (32.8\% of the western Ukrainian borderland indicator, WUBI) and Ivano-Frankivsk oblasts (19.0\% WUBI). Lowest is in the Transcarpathian (10.3\% WUBI) and Rivne oblasts (10.3\% WUBI). Higher amounts of religious educational institutions are in Lviv (39.4\% WUBI), Ivano-Frankivsk oblasts (33.3\% WUBI). The smallest are in the Volyn oblast (3.0\% WUBI). The average level of accredited religious educational institutions are larger in Volyn (28.0\% WUBI), Lviv (24.0\% WUBI), Ivano-Frankivsk (20.0\% WUBI), Transcarpathian oblasts $(16.0 \% \mathrm{WUBI})$ and the lowest in Chernivtsi oblast (4.0\% WUBI) (Fig. 1). Higher levels of religious educational institutions are not uniform in distribution, both in regions and in confessions.

The density of religious educational institutions to community, has a number of interconnectedness of religious schools and religious communities. The average ratio of religious schools to the region is 5.5 institutions/communities. The highest density is in Ivano-Frankivsk oblast, 8.3 institutions/communities, which is associated with one of the highest 


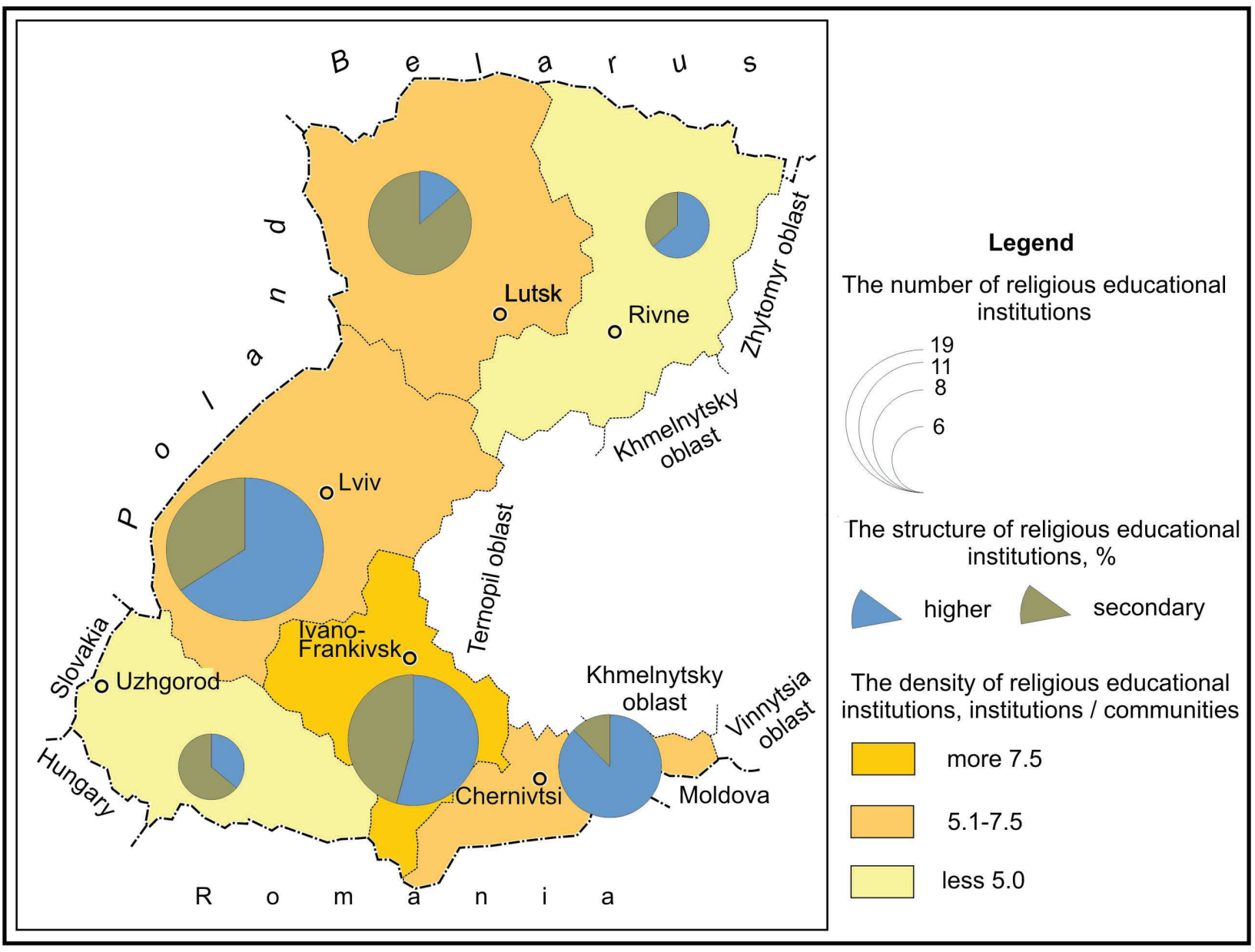

Fig. 1. Religious educational institutions of the western Ukrainian borderland, 2016

Source: own elaboration.

concentrations of religious schools to a small number of communities in the region. The lowest density is in Transcarpathian oblast. 3.3 institutions/communities which explains the large number of religious communities, a small area and a small number of religious educational institutions.

Christianity is the leading religion of the population in Ukraine. In the western area, the Orthodox Church is dominant. The most common religious organization is the Ukrainian Orthodox Church (Moscow Patriarchate). It is estimated to have 2560 religious organizations ( $23.3 \%$ of the region), nine departments, 2468 communities (23.5\%), 68 monasteries (30.4\%), one mission (1.2\%), seven religious schools (11.9\%), one higher level education (Volyn Theological Seminary (Lutsk)) and six secondary schools, where 713 students are enrolled. The employees of the church consist of 2438 clergy, including three abroad. Religious organizations: 22 printed periodicals, 12 other printed material, four electronic and six audio-visual.

In Ukraine, the past 90 years of the last century, popular nationalist ideology, caused a national restructuring and regaining control of the government.
We believe it was necessary. During this period, Ukrainian Orthodox Church (Kyiv Patriarchate) and the Ukrainian Autocephalous Orthodox Church united under one name, the Ukrainian National Orthodox (Ровенчак, 2008).

The composition of the Ukrainian Orthodox Church (Kyiv Patriarchate) in this region include 1786 religious organizations (16.3\%), 9 administrations, 1,740 communities (16.6\%), 23 monasteries (10.3\%), 4 missions (4.8\%), 8 religious schools (13.6\%), five higher level (Volyn Orthodox Theological Academy (Lutsk), Lviv Orthodox Theological Academy (Lviv), Rivne Seminary (Rivne), Ivano-Frankivsk Theological Institute (Ivano-Frankivsk), School of Philosophy and Theology of the Yuriy Fedkovych Chernivtsi National University (Chernovtsy) and three secondary schools, where 536 students are enrolled. There are about 1423 caretakers of the church which includes clerics, of which one serves abroad. The religious organizations produce 16 periodicals, five print material, four electronic and seven audio-visual.

Lviv Orthodox Theological Academy (LOTA), is a higher education institution of the Ukrainian Orthodox Church (Kyiv Patriarchate), which prepares 
priests, clergy and other church workers for all regions of Ukraine (Львівська православна...). Historical decision was made by Ukrainian Council of Ukrainian Autocephalous Orthodox Church on June 5, 1990 on the creation of Lviv Theological Seminary. Since 2003, administrative departments were created, which trains the choir, cantor and clerks with the right Christian ethics teaching in the secondary school. The academy has the following departments, scripture, theology, church history, social sciences and humanities.

Ukrainian Autocephalous Orthodox Church has 612 religious organizations $(5.6 \%)$, four administrations, 596 communities (5.7\%), 7 monasteries (3.1\%), one mission (1.2\%) and 3 religious educational institutions (5.1\%), one of which is higher (IvanoFrankivsk Seminary (Ivano-Frankivsk)) and two middle level with 75 enrolled students. Church has, 452 priests, publish 8 periodicals, including 5 printed and 3 electronic.

In the western Ukrainian borderland, it is part of traditional custom, to work and serve the Greek Catholic. As a religious organizations it has 10 senior kindergartens. In Volyn, Ivano-Frankivsk, Lviv, Rivne and Chernivtsi oblasts Ukrainian Greek Catholic Church has 2375 religious organizations (21.6\%), one center, 13 offices, 2260 communities (21.5\%), 66 monasteries (29.5\%), 22 missions (26.2\%), 12 religious educational institutions (20.3\%), of which 9 are senior level (Ukrainian Catholic University in Lviv), Ivano-Frankivsk Theological Seminary named Josaphat (Ivano-Frankivsk), Ivano-Frankivsk
Theological Academy of Greek-Catholic Church (Ivano-Frankivsk), Ivano-Frankivsk Theological University, St. John Chrysostom (Ivano-Frankivsk), Lviv Holy Spirit Seminary (Lviv), Basilian Institute of Philosophical and Theological Studies named Joseph Velyamyn Ruts'kyj (Lviv-Bryukhovychi), Drohobych Seminary of Blessed Martyrs Severin, Vitali and Yakima (Lviv oblast, Drohobych), the Institute of spiritual, Philosophical and Theological Studies named Bishop Nicholas Charnetsky Lviv province (Lviv), Diocesan Catechetical Institute of the Holy Trinity (Lviv oblast, Drohobych ) and 3 middle level schools with 1742 students enrolled. Those that serve the Church, 2001 clergy, 15 abroad. Religious organizations produce 32 periodicals, 20 of which are printed, 6 audiovisual and 6 electronic.

Ukrainian Catholic University consists of two faculties, Humanities (department: classical, Byzantine and medieval studies, world history, modern and contemporary, modern and contemporary history of Ukraine, (Culture and Languages), Philosophy and Theology; four institutions, Catechetical-Pedagogical, Economic Studies, leadership and management, mental health; lectures of the protection of national minorities, Christian Camp for Children, "My journey with Jesus and Friends" and language schools, English, German, Italian, French and English for high school students (Український католицький...). The university has an enrolment of about a thousand students as of 2016, of whom 274 are undergraduates and 260 are working towards masters degrees (Fig. 2).

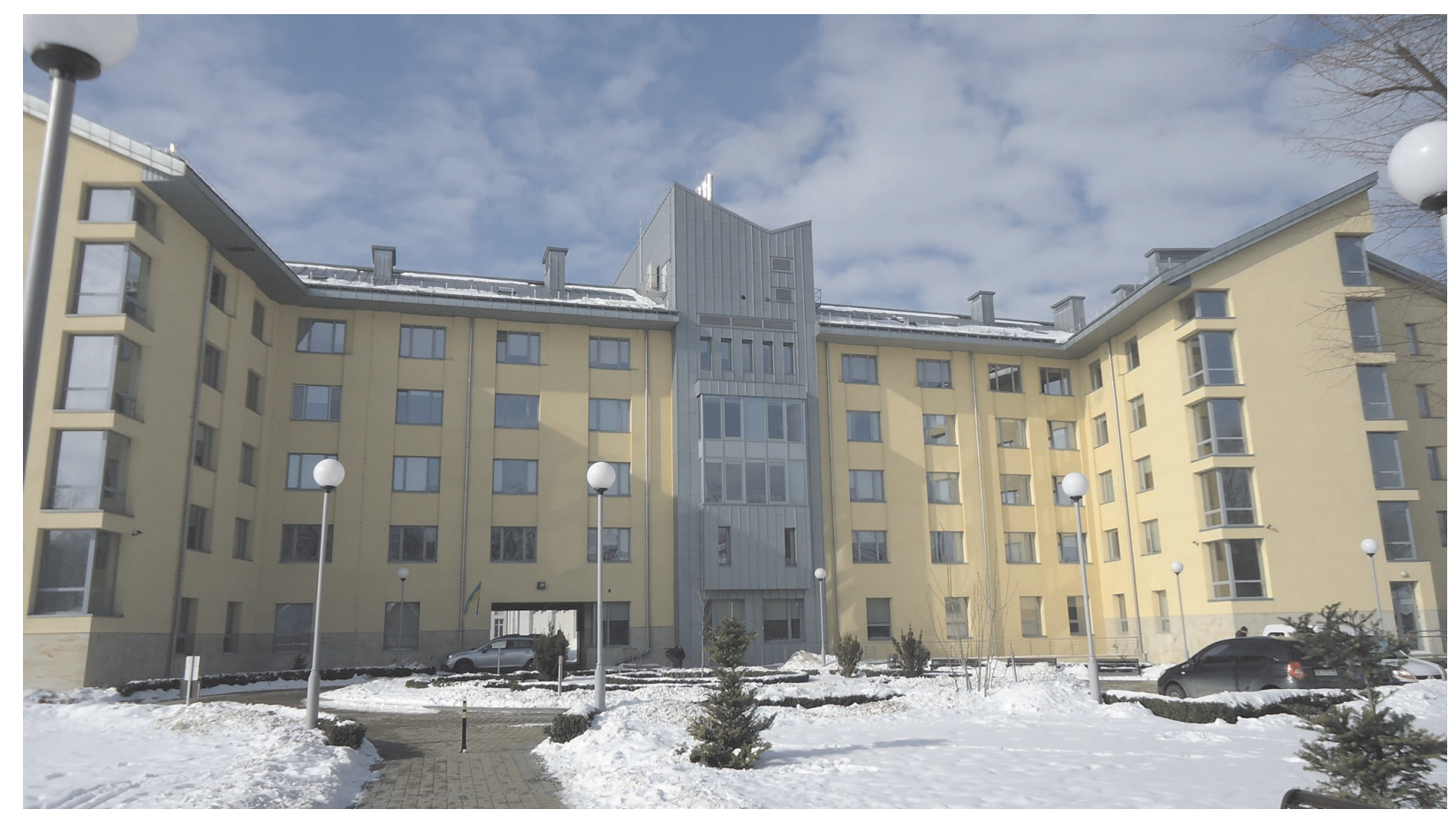

Fig. 2. Ukrainian Catholic University

Source: photo V. Stetskyi. 
In the Transcarpathian oblast, Mukachevo diocese of the Greek Catholic Church, includes 457 religious organizations (4.2\%), 2 administrative offices, 433 communities (4.1\%), 20 monasteries (8.9\%), religious educational institutions (1.7\%), Uzhgorod Theological Academy Theodore Romzha (Uzhgorod)), which receive 82 ordained trainees and 137 Sunday schools (2.4\%). Church has about 328 clergy, including 12 abroad. It publishes two journals, one is a print and the other in electronic form.

The Roman Catholic Church in Ukraine, is represented by 390 religious organizations (3.6\%), one center, 8 offices, 331 communities (3.1\%), 38 monasteries (17.0\%), 9 missions (10.7\%), three religious educational institutions (5.1\%), two of which are higher level (Lviv-Bryukhovychi), Major Seminary St. Joseph and the Archdiocese of Lviv Theological Institute named Archbishop of St. Joseph Bilczewski (Lviv Archdiocese of the Latin rite) and one middle level with 125 students are enrolled. Church employs 209 priests, including 109 abroad. Religious organizations print 7 periodicals, including 3 electronic and 4 printed.

The higher level Seminary of St. Joseph, Lviv Archdiocesis, operates the Theological Institute of St. Joseph Bilczewski Archbishop of the Latin Rite branch of the Catholic University of Lublin (Вища Духовна..., 2017; Теологічний інститут...,2017). Training at the Institute conducted in two courses - $A$ and $B$, the course $A-0$ to 6 years of practice, and the $B$ course -1 to 5 year seminars, electives and practical (Fig. 3).

Protestants religious organizations are distributed across all regions of the western region. Their first group are the Baptists, which include Evangelical Baptist Union of Ukraine, International Council of Evangelical Christians-Baptists (Chernivtsi oblast) and other Baptists (Volyn, Lviv, Rivne and Chernivtsi oblasts) There are a total of 663 religious organizations (6.0\%), 6 offices, 628 communities (6.0\%), 15 missions (17.9\%), 13 religious educational institutions (22.0\%) of which 7 are universities and 6 secondary schools, with a total of 3881 students. Affairs of the church cared by 927 priests, including 9 abroad. Periodicals produced are 6 , of which 4 electronic and two printed.

The Evangelical Baptist Union of Ukraine has seven senior kindergartens, Ukrainian Baptist Theological Seminary (Lviv), Rivne Biblical institute (Rivne) Rivne Regional Bible College (Rivne), 4 in the Chernivtsi oblast.

The second group are the Evangelical Christians represented by the Association of Missionary Churches of Evangelical Christians of Ukraine (Rivne oblast), Council of Independent Evangelical Churches of Ukraine (Rivne, Ternopil oblasts), Evangelical Christians (Volyn, Transcarpathian, Ivano-Frankivsk, Rivne, Chernovtsy oblasts). They have a total of 46 religious organizations (0.4\%), 1 center and 2 boards 38 communities $(0.4 \%), 3$ missions $(3.6 \%), 2$ middle schools (3.4\%), with 40 students. Church affairs are cared by 44 priests. They publish one of printed periodical.

The third group of Evangelical Christians includes All-Ukrainian Union of Christians of Evangelical Faith-Pentecostals and other Evangelical Christians, Union Church of God of Ukraine (Transcarpathian, Chernivtsi oblasts), Center of God Evangelical Christian Church of Ukraine Prophecy (Transcarpathian, Ivano-Frankivsk, Lviv, Rivne oblasts), Cathedral Church of Ukraine, Evangelical Christians "Open Bible" (Volyn oblast), Union of Free Churches of Christians of Evangelical Faith of Ukraine (Transcarpathian, Ivano-Frankivsk oblasts.). Total of these religious organizations is $924(8.4 \%), 2$ centers and 12 offices, 879 communities (8.4\%), 23 mission (27.4\%), 6 religious educational institutions (10.2\%) 5 universities and one middle school with an enrollment of 795

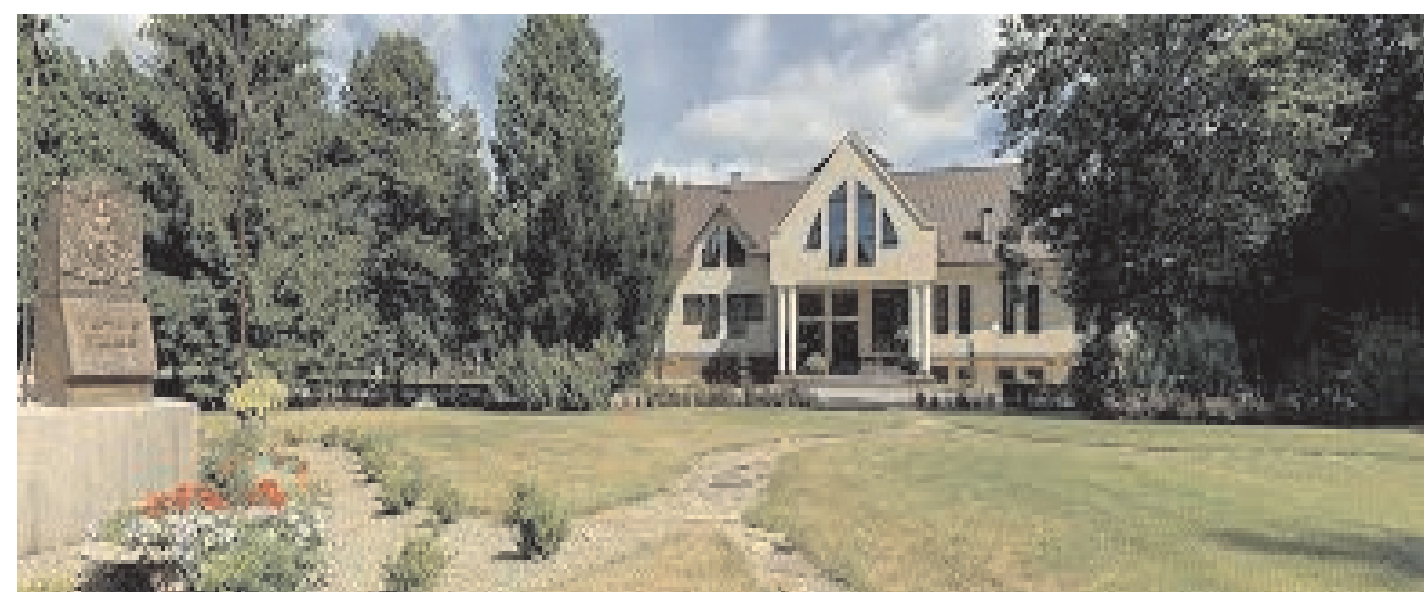

Fig. 3. Theological Institute of St. Joseph, Archbishop Bilczewski

Source: photos from the site - http://www.itlviv.org.ua/ 
students. Affairs of the church cared by about 1273 clergy, including 4 abroad. They publish 11 magazines, 5 of which are printed, 4 audio-visual and two electronic.

Ukrainian Union of Christians of Evangelical-Pentecostal has 5 senior kindergartens, Lviv Theological Seminary, Rivne Theological Seminary and another 2 in Lviv and Chernivtsi oblasts.

The fourth group are the Adventists, represented by the Ukrainian Union Conference of Seventhday Adventists and Seventh Day, Adventist Church Reform Movement of Ukraine (Transcarpathian, Chernivtsi oblasts), Other Adventist (Lviv, Chernivtsi oblasts). They comprise a total of 307 religious organizations (2.8\%), 1 center, 2 governing bodies, 299 communities (2.8\%), 2 missions (2.4\%), 2 senior religious educational institutions (3.9\%), with 106 enrollment. Affairs of the church cared by 289 priests, including one abroad. They produce 11 periodicals, of which 8 are print, 2 audio-visual and 1 electronic.

The fifth group are the Lutherans which include the German Evangelical Lutheran Church in Ukraine (Volyn, Lviv oblasts), Ukrainian Lutheran Church (Ivano-Frankivsk, Lviv, Chernivtsi oblasts) and other Lutheran religious organizations (Ivano-Frankivsk, Lviv oblasts.). There are 7 religious organizations (0.1\%), 7 communities $(0.1 \%)$. Affairs of the church are cared by 7 priests, including one abroad.

The sixth group are the Transcarpathian Reformed Church (Transcarpathian oblast), Ukrainian Evangelical Reformed Church (Rivne oblast) and other Reformed religious organizations (Transcarpathian, Lviv, Rivne oblasts). They composed 125 religious organizations (1.1\%), 1 center and 3 offices, 121 communities (1.2\%). Church affairs cared by 85 priests, including 7 abroad and they publish one printed periodical.

Another group are the Charismatics which include Association of Independent Charismatic Christian Churches of Ukraine, Full Gospel (Volyn, Transcarpathian, Lviv, Rivne oblasts), Ukrainian Christian Evangelical Church (Lviv oblast), Church of the Living God (Transcarpathian, Ivano Frankivsk, Lviv, Rivne oblasts), Spiritual Center "New Generation" of Christian churches in Ukraine (Lviv, Rivne oblasts), Spiritual Center "Renaissance" (Ivano-Frankivsk, Lviv oblasts). The total religious organizations is 184 (1.7\%), 4 centers, 2 governing boards, 166 communities (1.6\%), 2 missions (2.4\%), 2 middle religious schools (3.4\%) attending 40 students. Church affairs

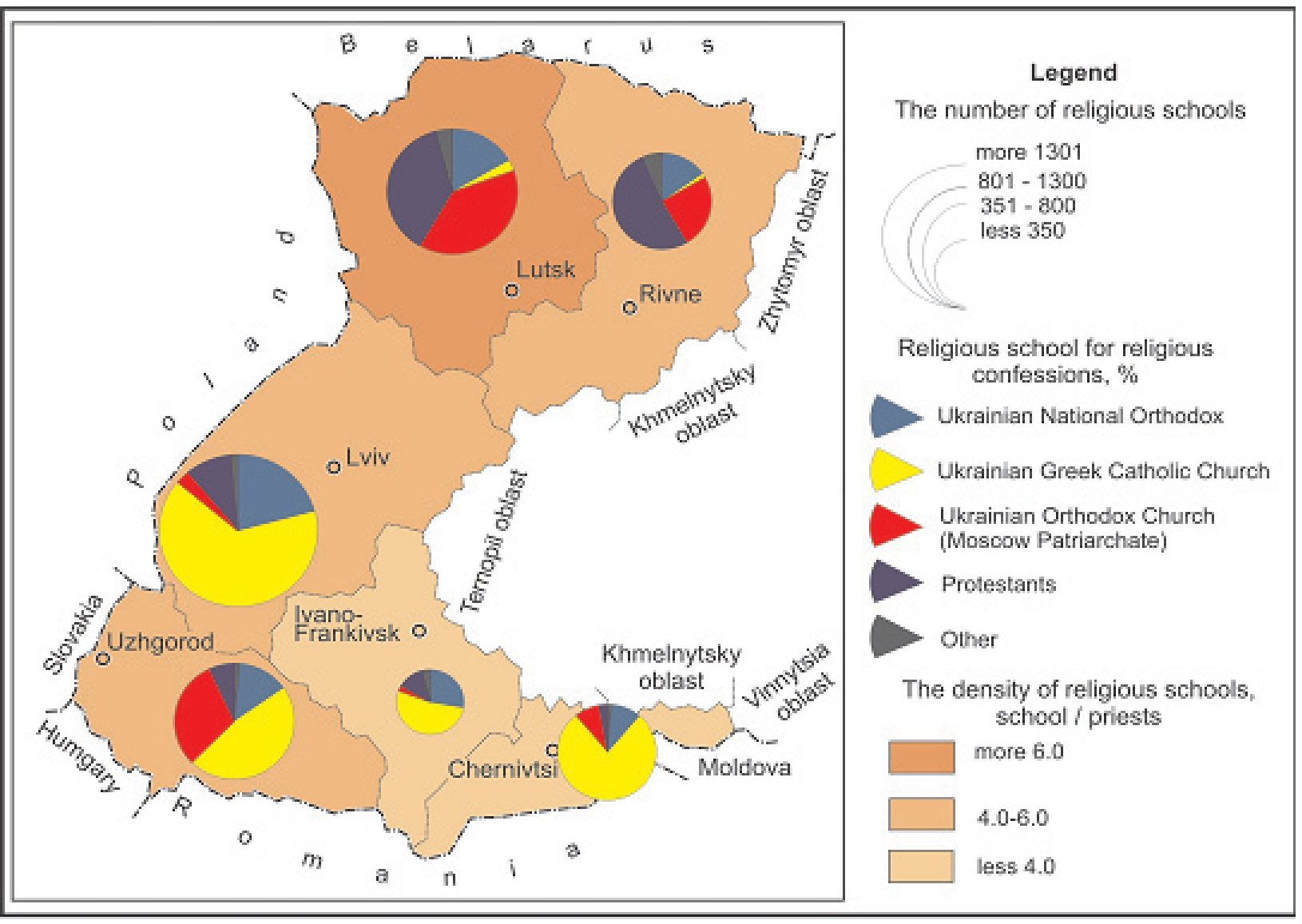

Fig. 4. Religious Schools in the western Ukrainian borderland, 2016

Source: own elaboration. 
are cared by 235 priests, including 11 abroad. They produce 12 periodicals, including 9 print, 1 audiovisual and 2 electronic.

Judaism includes United Jewish Organization of Ukraine (Transcarpathian, Ivano-Frankivsk, Lviv and Chernivtsi oblasts), Progressive Judaism (Volyn, Transcarpathian, Lviv and Chernivtsi oblasts), The Association of Chabad Hasidim Lubavitch Jewish Organization of Ukraine (Volyn, Rivne and Chernivtsi oblasts), Other Jewish religious organizations (Transcarpathian, Lviv and Chernivtsi oblasts). Total religious organizations is $44(0.4 \%), 44$ communities $(0.4 \%)$. Affairs of the congregation cared by $28 \mathrm{rab}-$ bis, including 9 abroad. One print material and one electronic periodical.

Besides the above mentioned religions and faiths represented in the territory they are few in the area, and their number is not very large and does not affect the overall situation in the region. These are the religious organizations: Protestants, Islamic, Buddhists, Ukrainian Diocese of the Armenian Apostolic Church, among the new ones are the Pagans, Oriental, and all others.

The density of religious schools/priests, depends on the number of schools, clergy, and community and religious schools. Medium density indicator within the western Ukrainian borderland is 5.02. The highest density in the Volyn oblast -8.3 , the lowest is in the Ivano-Frankivsk oblast - 1 (Fig. 4).

The next and equally important figures of religious schools, are the ones in general and the Sunday schools. Their number in the region is 56017, most of them are in Lviv oblast $(2054,27.4 \%$ regional) and the lowest in Ivano-Frankivsk oblast $(285 ; 3.8 \%)$. In the western Ukrainian borderland are four general religious organizations, namely the Ukrainian Greek Catholic Church in Ivano-Frankivsk (1. "Spiritual School" the Metropolitan Sheptytsky), Lviv (2. UC School Gymnasium, St. Sophia) and one, the Ukrainian Union Conference Adventist Church in Lviv.

Religious schools in the western Ukrainian borderland structure consists of Ukrainian National Orthodox - 794 (55.0\% of the NP of 1443), Ukrainian Greek Catholic Church - 1734 (85.3\%; 2033), Ukrainian Orthodox Church (Moscow Patriarchate) - 1185 $(32.0 \% ; 3707)$, Protestants religious organizations $1723(39.1 \%$; 4401) and other - 165 (27.7\%; 595). Historically the church influenced the western Ukrainian borderland, and it is because of this, it is most numerous. Ukrainian National Orthodox is very traditional Ukrainian, so it takes the lion's share (Tab. 2.)

In distributing Religious Schools there is a pattern, where there is a greater number of specific religious denomination, there is a higher number Religious Schools of the same confessions. In the Volyn oblast structure is as follows: Ukrainian National Orthodox - 197 (24.8\% of the region), Ukrainian Greek Catholic Church - 14 (0.8\%), Ukrainian Orthodox Church (Moscow Patriarchate) - 402 (33.9\%), Protestants religious organizations - 375 (21.8\%) and other - 28 (17.0\%). In the Transcarpathian oblast structure is as follows: Ukrainian National Orthodox - $8(1.0 \%)$, Ukrainian Greek Catholic Church - 137 (7.9\%), Ukrainian Orthodox Church (Moscow Patriarchate) - 520 (43.9\%), Protestants religious organizations - $310(18.0 \%)$ and others - 80 (48.5\%). Ukrainian Orthodox Church (Moscow Patriarchate) and Protestant religious organizations prevails in this area, we can explain it this way, first - they are remnants of former forced imposition of the "right" religion; second, the rapid spread and influence of something new in the nation.

In Ivano-Frankivsk oblast structure is as follows: Ukrainian National Orthodox - 66 (8.3\%), Ukrainian Greek Catholic Church - 141 (8.1\%), Ukrainian Orthodox Church (Moscow Patriarchate) - 2 (0.2\%), Protestants religious organizations - $34(2.0 \%)$ and

Tab. 2. Religious Schools for confessions in the western Ukrainian borderland, number, 2016

\begin{tabular}{|l|l|r|r|r|r|r|r|}
\hline \multirow{2}{*}{ № } & \multicolumn{2}{|c|}{ Regions } & \multicolumn{6}{|c|}{ Religious organizations } \\
\cline { 3 - 8 } & & $\begin{array}{c}\text { Ukrainian } \\
\text { thotional Or- }\end{array}$ & $\begin{array}{c}\text { Ukrainian } \\
\text { Greek Catholic } \\
\text { Church }\end{array}$ & $\begin{array}{c}\text { Ukrainian Ortho- } \\
\text { dox Church (Mos- } \\
\text { cow Patriarchate) }\end{array}$ & Protestants & Other & Together \\
\hline 1 & Volyn & 197 & 14 & 402 & 380 & 28 & 1021 \\
\hline 2 & Transcarpathian & 8 & 137 & 520 & 310 & 80 & 1055 \\
\hline 3 & Ivano-Frankivsk & 66 & 141 & 2 & 35 & 4 & 248 \\
\hline 4 & Lviv & 385 & 1436 & 25 & 103 & 1 & 1950 \\
\hline 5 & Rivne & 121 & 4 & 196 & 432 & 22 & 775 \\
\hline 6 & Chernivtsi & 17 & 2 & 40 & 468 & 30 & 557 \\
\hline \multicolumn{2}{l}{ Total } & 794 & 1734 & 1185 & 1728 & 165 & 5606 \\
\hline
\end{tabular}

Source: calculated by the authors. 
other $-4(2.4 \%)$. In the Lviv oblast the structure is as follows: Ukrainian National Orthodox - 385 (48.5\%), Ukrainian Greek Catholic Church - 1436 (82.8\%), Ukrainian Orthodox Church (Moscow Patriarchate) - $25(2.1 \%)$, Protestants religious organizations - $103(6.0 \%)$ and other - 1 (0.6\%). Art historically formed an important feature among highly religious population.

In the Rivne oblast structure is as follows: Ukrainian National Orthodox - 121 (15.2\%), Ukrainian Greek Catholic Church - 4 (0.28\%), Ukrainian Orthodox Church (Moscow Patriarchate) - 196 (16.5\%), Protestants religious organizations - $432(25.1 \%)$ and others - $22(13.3 \%)$. In Chernivtsi oblast structure is as follows: Ukrainian National Orthodox - 17 (2.1\%), Ukrainian Greek Catholic Church - 2 (0.1\%), Ukrainian Orthodox Church (Moscow Patriarchate) - 40 (3.4\%), Protestants religious organizations - 468 (27.2\%) and other $-30(18.2 \%)$. This situation is the result of the impact of new trends in society and influence of Protestant religious organizations from neighbouring oblasts to the east.

\section{Summary}

Geographical study of religious education is now at the primary level in Ukraine, it requires deeper study. The historical aspect of the development of religious education in the western Ukrainian borderland existed a very long time and has been a significant part of the development - from communal schools to famous universities - Ukrainian Catholic University.

We have analyzed territorial extension of religious educational institutions and religious school in the western Ukrainian borderland enables organizations and it enabled us to make the following conclusions: 1) the density of religious educational institutions are linked to the number of priests and religious communities; 2) the higher religious educational institutions and secondary religious schools search their place in the system of education; 3 ) the location of religious educational institutions is due to historical development of religious confessions; 4) the location of religious school has its own pattern - where is the greater number of specific religious denominations, there is a higher number of religious school of the same denomination; 5) the density religious schools depends on the number of schools, priests, and community and religious educational institutions.

\section{References}

Sutton J., 1994, Religious Education in Contemporary Ukraine: Some Courses of Study Analysed, Religion, State and Society, 22(2), 209-235.

Вища Духовна Семінарія святого Йосифа Львівської Архідієцезіï, http://rks.Iviv.ua/ [22.01.2017].

Державна служба статистики України, www.ukrstat.gov. ua/ [22.01.2017].

звіт про мережу черков і релігійних організачій в Україні станом на 1 січня 2016 року, http://data.gov.ua/dataset/ resource/ [22.01.2017].

Кучабський О.Г., 2000, Релігійна сфера обласного регіону: трансформачія і територіальна організація (на матеріалах Львівської області), PhD typescript: ЛНу ім. Івана Франка, Львів.

Львівська православна богословська академія, http://lpba. org.ua/ [22.01.2017]

Патійчук В.О., 1998, Територіальна організація релігійної сфери адміністративної області (на прикладі Волинської області): PhD typescript: Волинський держ. ун-т ім. Лесі Українки, Луцьк.

Ровенчак I.І., 2008, Географія культури: проблеми теорії, методології та методики дослідження, Видавничий центр ЛНУ ім. Івана Франка, Львів.

Стецький В.В., 2015, Освітній простір, географія освіти, суспільно-географічні дослідження обласних освітніх систем України, [in:] O.I. Шаблій (eds), Львівська суспільно-географічна школа: історія, теорія, українознавчі студіі: матеріали Всеукраїнської наукової конференції з участю закордонних учених, присвяченої 70-річчю кафедри економічної і сочіальної географії Львівського національного університету імені Івана Франка, ЛНУ ім. Іван Франка, Львів, 270-281.

Теологічний інститут імені Святого Аpхієnископа Йосипа Більчевського Львівської Архідієцезії латинського обря$\partial y$, http://www.itlviv.org.ua/ [22.01.2017].

Український католицький університет, http://ucu.edu.ua/ [22.01.2017].

Федорів Ю., 2007, Історія черкви в Україні, Вид-во “Свічадо", Львів.

Шаблій O.I. 2000, Географія релігії, [in:] Сочіально-економічна географія України, Світ, Львів, 457-474.

Шевчук Л.Т., 1999, Сакральна географія, Світ, Львів. 